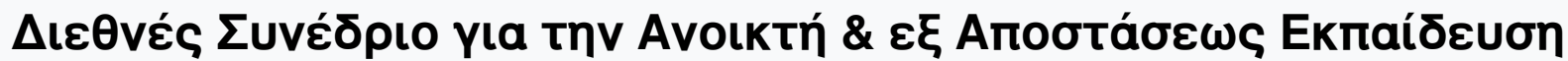

Tón. 7, Ap. 4A (2013)

Instructional Design and Curriculum Perspectives Applied in Online Teaching and Learning

Nelly Kostoulas-Makrakis

doi: $10.12681 /$ icodl. 712

Tónos 4, Mépos A doi: $10.12681 / i \operatorname{cod} 1.712$




\title{
Instructional Design and Curriculum Perspectives Applied in Online Teaching and Learning
}

\author{
Nelly Kostoulas-Makrakis \\ University of Crete \\ nkostoula@edc.uoc.gr
}

\begin{abstract}
This article discusses the basic instructional design and curriculum perspective applied in the development of an online Master of Science programme in the field of ICT in Education for Sustainable Development. First, a brief overview of the instructional design theories as they are used in the field of web-based distance education is provided. Second, the major philosophical ideas of curriculum perspectives as they relate to the instructional design theory adopted and education for sustainability are addressed. In the end it is discussed how the preferred instructional and learning design has been applied to online course development.
\end{abstract}

Keywords: Instructional design, curriculum perspectives, online learning

\section{Introduction}

With the rapid growth of computer networks and advances in information and communication technologies (ICTs), web-based distance education has become a major venue for delivering instruction and content. The distance education model that dominated for a long time is largely driven by objectivist approaches to teaching and learning that has its roots in behaviorist and cognitive theories. Various scholars (e.g. Higgins, 1998; Moore \& Kearsley, 2005; Peters, 2010; Zhang \& Kenny, 2010) argued that online education has shifted the focus from knowledge transmission to knowledge constructing and the role of the teacher from knowledge transmitter to that of a facilitator who provides considerable opportunities for interaction and meaningmaking to distant learners. Indeed, online learning has become a new paradigm for teaching and learning given the capability of expanding ICTs and the widespread concepts of constructivist-oriented open and distance life-long learning. In developing online courses, the instructional design approach and the curriculum perspective is of critical importance.

Instructional design principles adherent to objectivism are based on a technocratic, managerial and instructivist conception of teaching and learning that focuses in transmissive and standardized procedures. In a transmission-oriented learning approach, a teacher's job consists of planning a set of activities in which particular subject content is replicated to the learner's mind. Learning in this sense is simply defined as change in behavior and/or change in the learner's cognitive structures. Many instructional design models have been developed based on this approach such as those of Dick, Carey and Carey (2005) and Gagne, Wager and Briggs' (1992) models.

However, over the past two decades, instructional design principles and practices have shifted from objectivism to constructivism (Jonassen, 1992; 1994; Jonassen et 
al., 1995; 2003). Constructivism postulates that "knowledge is individually constructed and socially re-constructed by learners based on their interpretations of experiences in the world" (Jonassen, 1999: 217). Jonassen (1991) lists a number of design principles that can be used to develop what he calls the "constructivist learning environment". These design principles are as follows:

1. Create real world environments that employ the context in which learning is relevant;

2. Focus on realistic approaches to solving real-world problems;

3. The instructor is a coach and analyzer of the strategies used to solve these problems;

4. Stress conceptual interelatedness, providing multiple representations or perspectives on the content;

5. Instructional goals and objectives should be negotiated and not imposed;

6. Evaluation should serve as a self-analysis tool;

7. Provide tools and environments that help learners interpret the multiple perspectives of the world, and

8. Learning should be internally controlled and mediated by the learner (Jonassen: 11-12).

The instructional design principles adherent to online constructivist teaching and learning involve embedding learning in complex real world problems (authentic versus academic contexts), providing a rich, open and flexible learning environment with goals and objectives co-constructed or negotiated with the learner and errors are used as a mechanism for screening students rather than to provide feedback on learners' understanding. Constructivist models, in general, are based on a set of philosophical assumptions and provide designers with a set of flexible learning strategies and methods such as cooperative learning, project-based, problem-based learning, reflective learning, etc.

Although, in practice, a mix of objectivist and constructivist instruction/learning design is being used, it is of particular importance to expose the philosophical assumptions that guide human interest in designing instruction. Habermas (1971) differentiates three primary generic cognitive/human interests or learning domains termed as "knowledge constitutive interests" that are grounded in different worldviews. The first named technical interest broadly refers to the way one controls and manipulates one's environment to achieve certain learning results. It is commonly driven by an instrumental reason based upon empirical investigation of causal relationships. The empirical-analytic sciences using hypothetical-deductive theories characterize this knowledge interest. The second, named practical interest refers to human social interaction or 'communicative action' that is driven by binding consensual norms, which define human reciprocal expectations grounded in the intersubjectivity of the mutual understanding of intentions. Much of the historicalhermeneutic disciplines - descriptive social science, history, aesthetics, legal, ethnographic, and so forth are classified by Habermas as belonging to the domain of the practical human interest. The third, named emancipatory interest refers to critical self-reflection (emancipation) or praxis that is leading to a transformed consciousness or 'perspective transformation'.

\section{The ExConTra Learning Model}

In trying to bring together the main principles of the constructivist and tranformative learning theories, assuming that experiential learning is crossing the two (e.g. Kolb \& Kolb, 2005), Makrakis \& Kostoulas-Makrakis, (2012a) have conceptualised a 
construct abbreviated as ExConTra, that corresponds to Experiential learning, Constructivist learning and Transformative learning depicted in Figure 2.

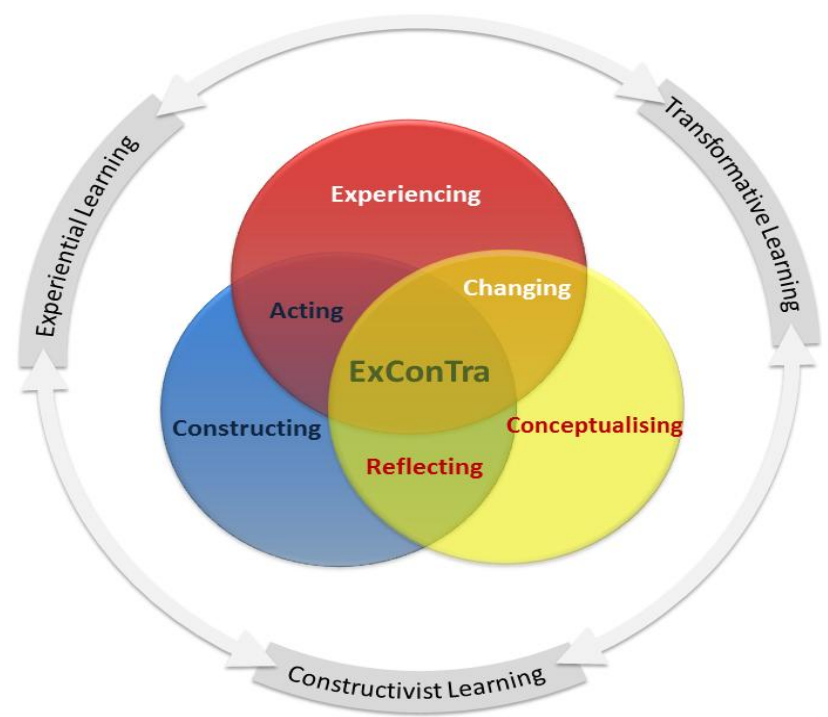

Figure 2: The ExConTra learning model

Beginning with experiencing, learners identify a realistic and authentic task associated with a sustainable development issue, and start collecting the information needed for their analyses, using various inquiry-based methods. Through reflecting, self and/or social, as well as through further reading and observing, learners organize and examine the collected data for the new experience from a variety of perspectives in order to find and make meaning. For learners to make meaning, either individually and/or shared, they need to reflect on their own experiences, leading them to develop more abstract understandings of their experiences (conceptualizing). Arriving at individual and shared meaning (constructing), learners need to get involved in a meaningful learning and shared inquiry enriched through continuous reflection, re-conceptualization and active experimentation. Constructed knowledge and meaning is meaningful when it opens up opportunities for action. Merging knowledge and meaning with action (acting) leads to a change agency and active citizenship. Acting as agents of change, learners are empowered to transforming experience through critical reflection and active experimentation. When critical reflection is transformed into an action it becomes praxis that turns learners able to transform oneself and society (transforming). To facilitate transformative learning, educators must help learners become aware and critical of their own and others' assumptions. Learners need practice in recognizing frames of reference and using their imaginations to redefine problems from a different perspective. In this sense, learning is a social process of effecting change in a frame of reference composed of real life habits of mind and a point of view (Mezirow, 2000; 2003). Frames of reference (cognitive, conative, and emotional) are the structures of assumptions through which we understand our experiences (ibid.).

In summary, an ExConTra teaching and learning approach in the field of education for sustainability enabled by ICTs attempts to turn experience, meaning making, knowledge construction and critical consciousness into praxis through critical 
reflection. This involves creating a virtual learning environment so that students (Makrakis, 2011; 2012; Makrakis \& Kostoulas-Makrakis, 2012ab):

- Identify sustainability issues and problems to be solved that make sense for them and their locality rather than handling issues and questions defined for them outside of their interest and context.

- Decide how to explore and investigate the identified sustainability issues or problems using various ICT tools and resources rather than being driven by others to find meaningless solutions.

- Reflect critically on constructed meaning and knowledge using various synchronous and asynchronous communication tools.

- Interact with peers, instructors and the community to interpret experiences, discuss ideas and solutions and receive fruitful feedback.

- Apply new understandings and knowledge to effect change at personal and societal level.

\section{Curriculum Perspectives and Human Interests}

Summing up, a technical interest is an interest to control, predict and manage the environment deeply-rooted on modes of inquiry, curriculum and pedagogy in the "empirical-analytic" or positivist sciences. Practical interest rooted in the interpretivehermeneutic sciences is an interest of mutual and self-understanding. Finally, the emancipatory interest is an interest of critical self-reflection, leading to empowerment, praxis and emancipation. The praxis model of curriculum theory and practice applied to ICTs makes an explicit commitment to their true emancipatory potential. Thus, the concept of praxis is not simply using ICTs to freeing people from lower cognitive demanded works, but a commitment to use ICTs as enabling tools to turn people able to act as agents of change. Each of the three knowledge-constitutive interests is expressed in a particular scientific or scholarly paradigm, directly or indirectly affects curriculum design, perceived education roles, teaching methods and pedagogy (Table $1)$.

Table 1. Habermas' three knowledge interests and their effects

\begin{tabular}{|l|l|l|l|l|}
\hline $\begin{array}{l}\text { Type of } \\
\text { Knowledge/ } \\
\text { Human Interest }\end{array}$ & $\begin{array}{l}\text { Perceived Role } \\
\text { of Education }\end{array}$ & $\begin{array}{l}\text { Virtual } \\
\text { Teaching \& } \\
\text { Learning }\end{array}$ & $\begin{array}{l}\text { Curriculum } \\
\text { Perspectives }\end{array}$ & Pedagogy \\
\hline $\begin{array}{l}\text { Technical } \\
\text { (prediction; } \\
\text { causality; } \\
\text { instrumentality) }\end{array}$ & $\begin{array}{l}\text { Reproduction/ } \\
\text { socialization/ } \\
\text { Vocationalization } \\
\text { roles }\end{array}$ & $\begin{array}{l}\text { Transmissive } \\
\text { Lecturing }\end{array}$ & $\begin{array}{l}\text { Product } \\
\text { oriented }\end{array}$ & $\begin{array}{l}\text { Behavioral/ } \\
\text { cognitive } \\
\text { Linear }\end{array}$ \\
\hline $\begin{array}{l}\text { Practical } \\
\text { (Understanding; } \\
\text { intersubjective) }\end{array}$ & Liberal role & Transactive & $\begin{array}{l}\text { Process } \\
\text { oriented }\end{array}$ & Constructivism \\
\hline $\begin{array}{l}\text { Emancipatory } \\
\text { (critical } \\
\text { reflection) }\end{array}$ & $\begin{array}{l}\text { Tranformative } \\
\text { role }\end{array}$ & Transformative & $\begin{array}{l}\text { Praxis } \\
\text { oriented }\end{array}$ & $\begin{array}{l}\text { Critical } \\
\text { pedagogy }\end{array}$ \\
\hline
\end{tabular}

In a transmissive virtual classroom model, driven by a technical interest, the focus is on linear pedagogies and pre-specified curriculum goals and content, which may lead both educators and learners to overlook the dynamic learning online interactions enabled by ICTs. The e-tutor is placed at the center of the learning process and is expected to transmit to students a prescribed subject (curriculum as product). Virtual lecturing and demonstration are the primary instructional methods. It is a virtual 
classroom in which students are to approach their learning working independently. They are also expected to neglect their personal interests, experiences and needs. The perceived role of education is that of replication of existing social, cultural and economic structures.

In contrast, the transactive virtual classroom driven by a practical interest focuses on flexibility, negotiation, active sharing and learning (curriculum as process). In other words, the questions of "what to teach?", "what to learn?" and even "how to learn?" are not predetermined but are open to intersubjective treatment. In this sense, the curriculum "is not simply a set of plans to be implemented, but rather is constituted through an active process in which planning, acting and evaluating are all reciprocally related and integrated into the process" (Grundy 1987: 115). In such a virtual model of online education, the e-tutor's role is one of a guide whose primary task lies in motivating and engaging students in the learning process. To accomplish this, the etutor creates problem-solving opportunities for students that are often based upon student experience. The perceived role of education as Sterling (2001) sets out what could/should be:

- To replicate society, culture and citizenship - a socialisation function

- To train for employment - a vocational function

- To develop the individual - a liberal humanist function

- To encourage a fairer society and a better world - a transformative function

The last role is seen by Sterling as central to achieve a more sustainable educational system. The first two roles mirror ideologies adherent to curriculum as product, the third, curriculum as process and the fourth curriculum as praxis. In a transformative virtual classroom model, driven by emancipatory interest the focus is placed on empowering, critical consciousness and reflection (praxis). Students can transform their frames of reference through critical reflection of their assumed assumptions concerning interpretations, beliefs and habits of mind or points of view.

\section{Applying an ExContra learning design in online course development}

In the virtual learning environment of the M.Sc. on ICT in education for sustainable development, students working in teams can be linked to a designated team area forum, where they can communicate and discuss with their team members and instructor their projects. Also, students can access a common forum area, where they can interact with the instructor and other members of the virtual class. Links to learning resources are provided such as the partners' university libraries, where they can search for additional readings.

These processes can further be enriched by ICTs as they provide many opportunities for experiential, constructivist and transformative learning experiences, especially by enabling learning to be related to context and to practice. Students are provided with an array of powerful tools that may transform teaching and learning processes and turn them able to take greater responsibility for their own learning and constructing their own knowledge. For example, through an activity in the first module for the ESD Pedagogy and ICT course students can use the open source video-conferencing tool BigBlueButton (http://www.bigbluebutton.org/), in groups of 4-5 to discuss the evolution of ESD in the light of sustainability crisis. The results of each group's discussion will be summarized in a wiki, to be presented in a whole group forum. Each group will assign one to present the wiki. In the follow-up activity the same groups with the help of a moderator will be engaged in a synchronous debate to define what they mean by the term 'sustainability literacy' and why it is so important. Questions to be discussed include: What competences does the sustainability literate 
person have? What knowledge, skills and values? Who/what has defined the concept? What are the links between sustainability literacy and political/social literacy? A final outcome of this activity would be to create as a class the profile of the ESD Educator, based on the student beliefs and understanding. This activity can act as an anchor point for Module 2 and 3. In another activity in module 2, students are invited to organise a discussion forum to reflect on the role of education and educator for sustainability. In particular, they are asked to form three oppositional parties: one will present and defend neoliberal policies on sustainable development and education; the second, social democratic policies on sustainable development and education and the third, radical policies on sustainable development and education. The moderator will summarise the arguments in a power point presentation. In a whole-class forum, all moderators are going to present the results of their groups, and a new whole group discussion will take place to explore differences and similarities of the key positions assumed by each group and the implications for the role of educator/practitioner. Through this discussion, a wiki will be created on the issue to represent the whole class. Students are requested to offer suggestions on how they (as teachers) could immediately employ ESD Pedagogy in their everyday work. In this assignment, students must identify any possible difficulties might arise from their attempt to employ ESD pedagogy in an actual classroom (e.g. contrasting goals with the current curriculum, inadequate learning tools, etc).

The above examples show that online collaborative discussions are increasingly notable for their role in social construction of knowledge by providing shared virtual workspaces for brainstorming, debating, discussing, or reflecting on issues of learning among learners, instructors or even invited guest speakers (Lim, 2007: 45). Both synchronous and asynchronous online discussions can foster critical reflection and create a foundation for transformative learning.

\section{Concluding Remarks}

Although the concept of instructional design was derived from behaviorist psychology, the evolution of instructional design has reflected principles of cognitive psychology, which has greatly influenced the processes of instructional design. The dominated transmissive approach based on a theory of learning which suggests that students will learn facts, concepts, and understandings by absorbing the content through a systematic and highly prescribed body of knowledge has shifted in recent years to an instructional design approach that is more constructivistic oriented. This shift has been highly influenced by advances in information and communication technologies that enable more open and interactive learning environments.

It is discussed that instructional design practitioners tend to adopt a mixed or eclectic instructional design model that integrates elements of various instructional design models with contrasting philosophical assumptions. Indeed, some learning problems may require prescriptive solutions, whereas others may need more flexibility to accommodate different learning styles and roles of education. Although it might be practical to use a mixed instructional design, it is of critical importance to consider the philosophical orientations inherent in our instructional design preferences since every decision concerning instructional design is driven consciously or unconsciously by a certain human interest. The ExConTra learning environment was used here as the general framework for the design of an online M.Sc. course which derives its philosophical assumptions from critical pedagogy. ICTs may help online students to become critical thinkers and problem solvers as well as to embark on personally relevant paths of discourse and inquiry, if online technologies are grounded on sound 
pedagogies. Adopting ExConTra learning enabled by ICTs opens higher potentials for self-reflection and critical discourse in dealing with sustainability issues.

\section{References}

Dick, W., Carey, L., \& Carey, J. O. (2005). The systematic design of instruction $\left(6^{\text {th }}\right.$ ed.). New York: Allyn and Bacon.

Gagné, R. M., Wager, W. W. \& Briggs, L. J. (1992). Principles of instructional design (4 ${ }^{\text {th }}$ ed.), New York: Holt, Rinehart and Winston.

Grundy, (1987). Curriculum: Product or praxis. New York: The Falmer Press.

Habermas, J. (1971). Knowledge and Human lnterests. Trans. Jeremy J. Shapiro. London: Heinemann. Higgins, A. (1998). Winds of Change and Paradigm Shifts: Correspondence, Distance

and Open Learning. Journal of Distance Leaming, 14 (1), pp. 23-29.

Jonassen, D.H. (1991). Objectivist vs. constructivist: Do we need a new philosophical paradigm? Educational Technology: Research and Development, 39(3), 5-14.

Jonassen, D. (1992) Objectivism versus constructivism: Do we need a new philosophical paradigm? ETR\&D, Vol. 39, No.3, pp.5-14.

Jonassen, D. H., (1994). Thinking Technology: Toward a constructivist design model. Educational Technology, 34(3), 34-37.

Jonassen, D. H. (1999). Designing constructivist learning environments. In C. Reigeluth (Ed.) Instructional design theories and models: A new paradigm of instructional theory (Vol. 2, pp. 215-239), New Jersey: Lawrence Erlbaum Associates.

Jonassen, D., Davidson, M., Collins, C., Campbell, J., and Haag, B.B., (1995). Constructivism and Computer-Mediated Communication in Distance Education. The American Journal of Distance Education, 9(2), 7-26

Jonassen, D. H., Howland, J. L., Moore, J. L., \& Marra, R. M. (2003). Learning to solve problems with technology: A constructive perspective (2nd ed.). Upper Saddle River, NJ: Prentice Hall.

Kolb, A.Y., \& Kolb, D.A. (2005). Learning styles and learning spaces: Enhancing experiential learning in Higher Education. Academy of Management Learning \& Education, 4(2), 193-212.

Makrakis, V. (2011a). Strategies for change towards sustainability in tertiary education supported by ICT. In ICT in Teacher Education: Policy, Open Educational Resources and Partnership (152166). IITE: UNESCO Institute for Information Technologies in Education.

Makrakis, V. (2011b). ICT-enabled education for sustainable development: Merging theory with praxis. In M. Youssef \& S. Aziz Anwar (Eds.), Proceedings of the 4th Annual Conference on e-Learning Excellence in the Middle East 2011 - In Search of New Paradigms for reEngineering Education (410-419). Dubai, UAE: Hamdan Bin Mohammed e-University.

Makrakis, V. (2012). Exploring university students' competence on learning to live together sustainably: An international survey research. Paper presented in the $16^{\text {th }}$ UNESCO APEID International Conference "The Heart of Education- Learning to Live Together. 21-23 Nov. Bangkok, Thailand.

Makrakis, V. \& Kostoulas-Makrakis, N. (2012a). The Challenges of ICTs to Online Climate Change Education for Sustainable Development: The ExConTra Learning Paradigm. In S.A. Anwar (Ed.), Proceedings of the 5th Conference on eLearning Excellence in the Middle East Sustainable Innovation in Education (594-605). Dubai, UAE: Hamdan Bin Mohammed eUniversity.

Makrakis, V. \& Kostoulas-Makrakis, N. (2012b). Online course design for a Joint M.Sc. Programme on ICT in education for sustainable development. In S.A. Anwar (Ed.), Proceedings of the 5th Conference on eLearning Excellence in the Middle East - Sustainable Innovation in Education (627-636). Dubai, UAE: Hamdan Bin Mohammed e-University.

Mezirow, J. (2000). Learning to think like an adult: Core concepts of transformation theory. In J. Mezirow (Ed.), Learning as Transformation: Critical Perspectives on a Theory in Progress (3-34). San Francisco, CA: Jossey-Bass.

Mezirow, J. (2003). Transformative learning as a discourse. Journal of Transformative Education, 1(1), $58-63$.

Moore, M.G., \& Kearsley, G. (2005). Distance education: A systems view $\left(2^{\text {nd }}\right.$ ed.). Belmont, CA: Wadsworth

Peters, O. (5th ed. 2010). Distance Education in Transition. BIS-Verlag der Carl von Ossietzky Universität Oldenburg. Available at http://www.unioldenburg.de/fileadmin/user_upload/c31/master/mde/download/asfvolume5_5_ebook.pdf 
$7^{\text {th }}$ International Conference in Open \& Distance Learning - November 2013, Athens, Greece - PROCEEDINGS

Sterling, S. (2001). Sustainable education - Re-visioning learning and change. Dartington: Green Books.

Zhang, Z \& Kenny, R. (2010). Learning in an Online Distance Education Course: Experiences of Three International Students. The Internation Review on Research in Open and Distance Education. 11 (1). Available at http://www.irrodl.org/index.php/irrodl/article/view/775/1481 